\title{
Rural Land Rights and Limitations in Ethiopia: The Study of Amhara Region
}

\author{
Sibuh Gebeyaw Tareke \\ Department of Land and Environmental Law, Bahir Dar University, Bahir Dar, Ethiopia
}

\begin{abstract}
According to Federal Democratic Republic of Ethiopia/ FDRE constitution, land is a common property of the Nations, Nationalities and Peoples of Ethiopia and shall not be subject, to sale or to other means of exchange. Thus, the peasants have the right to obtain land without payment and the protection against eviction from their possession. The peasants are permitted by the holding right, which include the lifetime use of rural land. But, there are a number of restrictions and prohibitions imposed on peasants holding right by the law. These restrictions include inadequate duration of rights, prohibitions imposed on transfer of holding right and absence of adequate compensation during expropriation. Because of these restrictions, peasants are prohibited to do things, whatever they want in their farmland. In doing so, by using primary and secondary data, this article explores the extent of land rights and limitations of peasants' and providing some amendments of constitutional law on peasants holding right generally in Ethiopia, particularly in Amhara region.
\end{abstract}

Keywords: - Land Right; Land Tenure; Tenure Security; Expropriation; Compensation; Constitution and Ethiopia. DOI: $10.7176 / \mathrm{JEES} / 11-3-03$

Publication date:March $31^{\text {st }} 2021$

\section{INTRODUCTION}

Access to land for the rural population is essential for food security and economic development in developing countries. Therefore, access to land is an effective tool for poverty reduction (Gerstter, 2011, p.5). In Ethiopia, rural land is a central element in the overall development and agriculture is a main source of income and livelihood for a segment making 85 percent to 90 percent of the country's population (Zewdu, 2002, p.23). Thus, the current government, Ethiopian Peoples' Revolutionary Democratic Front (EPRDF) came into power with free market economy, philosophy. Then, the 1995 FDRE constitution permitting free access to rural land for all Ethiopians, who want to engage in agriculture for a living. The peasants are entitled to the holding rights which include the lifetime use of rural land for agricultural purposes as well as lease [Proclamation No. 456/2005 Article 5 (1)].

The remaining attributes of the tenure system in both the federal and the Amhara National Regional State (ANRS) are not allowed as a full right for the reason of tenure security and social equity. As a result of these reasons, there are some restrictions and prohibitions imposed on peasant's holding right by the law. These are restrictions imposed in relation to rights on land, limitations imposed on transfer of holding right through inheritance, donation and lease as well as selling, mortgage, the right to collateral and exchange of the land is prohibited. The other limitation is the absence of adequate, timely and sufficient compensation during expropriation and wide grounds of expropriation and failure to compensate lose by using right due to expropriation. These restrictions have a negative impact on peasants and peasants are dispossessed to do things, whatever they want in their farmland (Weldegebreal, 2013b, p.270).

In doing so, the research seeks to achieve the following objectives: (1) to assess the scope of land rights in Ethiopia and Amhara region and (2) to investigate limitations of peasants' right over rural land and resolutions for the existing constitutional land holding problems. The structure of the article is; as follows: Section two, briefly discusses the empirics on land right, land tenure and tenure security; Section three, elaborates the methodology of the study; Section four to explore the nature of current rural land rights and limitations of peasants' in Ethiopia and Amhara region; Section five, provides the conclusion and recommendation remark.

\section{EMPIRICS ON LAND RIGHT AND LAND TENURE}

Land rights are recognized as rights arising from the past, present and future contributions of farmers in safeguarding, humanizing and making available natural resources for food and agriculture (Feyissa, 2006, p.1). It is also a"social conventions that regulate the distribution of the benefits that ensue from specific uses of a certain piece of land" a number of points of view hold up public provision of such rights (Belay, 2010,p.16). In the first place, the high predestined cost of the institutional infrastructure needed to institute and permanently maintain land rights favors public prerequisite, or at least regulate. Second, the benefits of being able to exchange land rights will be realized only in cases where such rights are standardized regulated and can be easily and autonomously verified. Finally, without central provision, households and entrepreneurs will be forced to spend resources to defend their claims to property, for example through guards, fences, etc., which is not only socially inefficient, but also extremely shortcomings the poor, who will be the least able to have enough money such expenditures. Therefore, land rights are the rights of an individual or group of individuals which comprises to use the land for 
different purposes like that of yield production, relocate the land through bestow, lease and exclusive use of those rights, whatever they need (Ibid, 2010).

Whereas, the issue of land tenure is the key and a pivotal concept in the economic status of the country as far as landing right is concerned (FAO, 2002,p.7). According to FAO land tenure defines as: -"The relationship, whether legally or customarily defined, among people, as individuals or groups, with respect to land". It is also defined as an institution, i.e., rules invented by societies to regulate behavior. Rules of tenure define how property rights to land are to be allocated within societies. They define how access is granted to rights to use, control, and transfer land, as well as associated responsibilities and restraints. In simple terms, land tenure systems determine who can use what resources for how long, and under what conditions (FAO, 2002,p.8).

In other ways, it is a social agreement that defines the relationships between individuals and groups of individuals by which rights and responsibilities are defined with respect to control and use of land. Additionally, the centrality of land in all extent of rural life in the context of Africa means that, the analysis of land tenure issues should be "widened from its traditional links with issues such as land-use, agricultural production efficiency, and access to credit, conflict management mechanisms, fragmentation of landholdings and the like, to include all aspects of political and social situations" (UNECA,2004, p.3). The experiences of many countries concerning land show that farming plots, residential land plots, buildings, easements (streets to serve the land property) are owned privately. In western countries, forest land, small lakes, streets and rural roads are also subject to private ownership (Snare, 1972, p. 9).

According to World Bank (2003), tenure security is a widely accepted norm that the prevalence of secured land tenure increases the future value of the land, encourages long-term investment on the land, can reduce environmental degradation, and allows reduction of private spending on security of property rights. To assure tenure security, there are three features of tenure system which measure the nature of peasants' land right; 'duration of the right over the land; the specific grounds under which peasants lose their rights and the healthiness of the right'. The longer the duration, the more secured tenure, which in return encourages making long term investment in their land. Losing holding right must be very narrow and supported by adequate and timely payment of compensation in advance. If peasant's right is strong, the holder should be granted the right to use their plot of land, transfer their holding right through lease, donation and inheritance to any person they want and permit them full ownership over the product they produced over the land without high restrictions (p.68). Moreover, scholars argue that, expropriation of land by the government without adequate compensation, leads to restriction on the amount of land that can be rented/ leased out and short periods for land leases and rent controls (Bekure, 2006,p.46).

In the case of Ethiopia, the last 50 years of the twentieth century were devastating, particularly regarding its political and agrarian history. The period was marked by revolutionary changes in state and class structure and in tenure relations and agrarian institutions. Even there is no separate and comprehensive policy in relation to rural land tenure and administration in Ethiopia (Rahimato, 2004,p. 33;Alemu, 2009,p.68). Tesfaye Teklu (2014), in his article 'Rural Land Rights and Security in Cultivated Highland Ethiopia', argued that in the early years, the land reform was characterized by widespread land confiscation, and major and frequent land redistribution. Farmers witnessed frequent redistribution or readjustment of their holdings, instability in their tenure, and uncertainty in their user rights. Again he concluded that, insecurity in tenure was heightened particularly in the 1980s as the regime in power halted redistribution of land and pushed on agricultural collectivization to hasten the drive for the socialist transformation of the agriculture economy (p.102).

On the other hand, Teklu has raised different issues in the current Ethiopian land tenure system, that is, farmers' access to land through three ways. The first way is to acquire land is through the administrative allocation. It is a constitutional right for peasants to have access to administratively allocated land for their livelihood. Access is free of charge, provided they are at least 'local resident, eighteen years of age and dependent on farming for their livelihood'. The collection of rights in land obtained comprises use right, short-term transfer right - renting or sharing land for short duration, long-term transfer- bequeathing land, private ownership of assets built on land, and right to compensation in the event of expropriation of one's landholding for public purpose. With these rights, he emphasized the following duties on peasants, such as demonstration of dependency on farming for a livelihood, permanent residency, compliance with land use and management guidance, and not engaging in land sale, exchange and mortgaging.

The other way of acquiring land is by renting, particularly in areas where population density is high, rural infrastructure is developed, and agriculture is commercialized. Access to rental is not a right. Instead, it is qualified on established capability to cultivate and provide inputs for production. Use rights in rental land are limited; tenant farmers are restricted in their production choices and land management practices. And they cannot transfer rental land in any form to a third party (p.102). Lastly, inheritance as a means of land acquisition is the same as the rights in land obtained through administrative allocation. Inheritance is the passage of title and ownership of property from the one who dies for people whom the law designates because of blood or marriage relation as the deceased heir by operation of the law or by the will of the deceased. In other words, it is the devolution of the property of the deceased to persons on the basis of close blood relation to the deceased (Ibid). 
On the other hand, concerning with farmers' access to land, Zambia proposes a number of measures. Currently, every farmer in Zambia will get land without any restriction unlike in Ethiopia. Moreover, its land policy marked the assurance of the disabled persons and people with HIV/AIDS, will access land like any other persons without any restriction whatever they live in different parts of the country (Molen, 2008, p.13). However, the current land policy of Ethiopia, the rural land administration and proclamation No.456/2005, is not consistent with policy provision. The presence of minimum parcel size, limited in loose right in terms of duration and size of leased land, the problem of proper land redistribution and certification laws, absence of clear land use guidelines, and deficient rural land dispute resolution mechanisms are futures of the current rural land policy and laws (Alemu, 2009, p.68).

Whereas the National Land Policy of Uganda, describes land administration as :- Land rights administration comprises the structures and processes through which rights in land are created, refined, and recorded or certified; the integrity of land transactions is assured and guaranteed, land rights disputes are processed,land revenue is generated, and land information is inventoried. The land rights administration system must be designed and operated with a view to enhancing and facilitating the management of land resources; and ensure that land rights administration structures and processes at all levels are transparent, cost-effective and accessible to the ordinary land using public (Ministry of Lands, Housing and Urban Development, 2007).

Yigremew Adal (2009), in his article on 'rural land tenure and women's land right in Ethiopia' had raised related issue with the research under study. Incidentally, he criticized the current land policy of Ethiopia for the following reasons: "statutory land right in Ethiopia is not Ethiopian". He argued that, public ownership of land, restriction of free access and use right of rural land only to those who engage in agriculture for living, absence of legal pluralism are major factors which impede rural land tenure security in general and women in particular (p.67). Furthermore, the law denied peasants to use holding right as collateral to have access to credit, while allowing investors to use their lease right for the same purpose. Again, peasants are not allowed to transfer their holding right to persons other than their family members. Family members are persons who live permanently with the landholder by sharing the livelihood of the latter. In the times of expropriating peasants have not adequate, timely and sufficient compensation and failed to compensate lose by using right due to expropriation (Woldegebreal, 2013a, p.49). On the other hand, the Amhara National Regional State (ANRS) Land Administration and Use Proclamation (LAUP) allowing inheritance of land by will to any farmer engaged in agriculture, by contrast, it does not allow inheriting rural land to one's children who live elsewhere in other professions and also not allow to spouse inheriting rural land, if not the spouse remains unmarried and continues living in the area of parents (Ibid).

On the other way, access to land on the basis of gender, ethnicity, or social and economic status without discrimination, or denying anyone, Uganda goes further to demand enforcement of the law requiring spousal consent for all transactions involving family or community land. Besides, Uganda calls for the simplification of access to land by the poor through a mechanism free of excessive bureaucracy. Likewise, in Tanzania, the government has a duty to protect the free enjoyment of legally acquired property rights in land, a landholder is entitled to prompt, fair and adequate compensation if the owner's property happens to be acquired by the government for public use. Even the policy further provides that acquisition of public interest may be challenged in a court of law, if and where the land holder acquired adequate compensation. Kenya, proposes to put in place a mechanism for redistribution of land and resettlement of internally displaced people and protecting their land rights from unjust and illegal expropriation (Molen, 2008, p.10-20).

Gudeta Seifu (2009), as dealing with 'Rural Land Tenure Security in Oromia Region', with the exception to other literatures made on tenure security in Ethiopia, focused on the instrumentality of the law in promoting tenure security and addressed the merit and drawbacks of the law to achieve rural land tenure security in Oromia region. In his article he tried to appreciate the merit of the provision of free access to rural land, lifelong use right, restriction and certification of rural land as guarantee for tenure security. On the other hand, he criticized the law on the bases of presence of wide grounds of expropriation with insufficient compensation, restriction on peasants right on transfer of use right through donation, inheritance and lease and prohibition on the right to depose private property over the land are drawback of the law that affect tenure security (p.113).

\section{METHODOLOGY OF THE STUDY}

The research method of this article uses both quantitative (numerical inquiry) and qualitative research techniques. A qualitative research which does not rely on statistical analysis, but involves some sorts of interviews and observations (Hejase and Hejase, 2013, p.112). It employs both primary and secondary data. The primary source, includes; interviews and relevant proclamations. Secondary sources include different text books, reports, articles and related sources. The instruments and strategies for collecting data included semi structured-interviews and particular questions which seem inappropriate with a particular interviewee can be omitted, or additional ones included. The questions were designed to meet the objectives of the study. The discussion was undertaken intentionally with 2 leaders and 2 selected experts working in Amhara, National, Regional State /ANRS/ Bureau of Land Administration and Use /BoLAU, and ten farmers in Maksegnut wereda and Raya-Kobo woreda as seen 
in Table 1. The data analysis used a qualitative narrative analysis conducted to analyze and interpret the data and the researcher should derive his explanations of the phenomenon in question by looking closely at the empirical data that have been collected.

\section{Table 1: List of Respondents}

\begin{tabular}{|l|l|l|l|l|}
\hline No & Name & Affiliation & Woredas & Date of interview \\
\hline 1 & Ato Addisu Molla & $\begin{array}{l}\text { Land Administration Expert of } \\
\text { ANRS/BoLAU }\end{array}$ & Bhirdar & April 8, 2016 \\
\hline 2 & Ato Amare Belay & A farmer & Raya-Kobo & April 8, 2016 \\
\hline 3 & Ato Ayizwachihu Chagne & A farmer & Maksegnut & March 23, 2016 \\
\hline 4 & Ato Beyene Wesen & A farmer & Maksegnut & March 23, 2016 \\
\hline 5 & Ato Deribew Wubu & A farmer & Raya-Kobo & April 8, 2016 \\
\hline 6 & Ato Fenta Dejen & Heads of ANRS/BoLAU & Bahir Dar & April 28, 2016 \\
\hline 7 & Ato Kassa Aweke & A farmer & Raya-Kobo & March 23, 2016 \\
\hline 8 & Ato Marie Gzahegn & A farmer & Maksegnut & April 8, 2016 \\
\hline 9 & Ato Molla Kebede & A farmer & Raya-Kobo & March 23, 2016 \\
\hline 10 & Ato Muhabaw Teshome, & A farmer & Maksegnut & April 8, 2016 \\
\hline 11 & Ato Solomon Berihun & A farmer & Raya-Kobo & April 28, 2016 \\
\hline 12 & Ato Tamirat Demisse & Animal Science Study Expert of & Bahir Dar & April 28, 2016 \\
\hline 13 & Ato Yehunew Abebe & Deputy Heads of ANRS /BoLAU & Bahir Dar & March 23, 2016 \\
\hline 14 & Ato Yigzaw Mengesha & A farmer & Maksegnut & March 23, 2016 \\
\hline
\end{tabular}

\section{THE NATURE OF CURRENT RURAL LAND RIGHTS IN ETHIOPIA}

According to Article 40 (3) of the FDRE constitution (1995), "the right to ownership of rural and urban land, as well as all natural resources, is exclusively vested in the State and in the peoples of Ethiopia. Land is a common property of the Nations, Nationalities and Peoples of Ethiopia and shall not be subject to sale or to other means of exchange". Concerning administrative matter the constitution empowered regional governments to administer land and other natural resources in accordance with the federal law [FDRE Constitution, 1995, Art 52 (2)].

Regards to its means of attainment, sub - Article 4 states that Ethiopian peasants have the right to obtain land without payment and the protection against eviction from their possession [FDRE constitution, 1995, Article 40 (4) (5)]. It means that peasants shall not have ownership rights to the land itself, rather as it illustrates in sub-Article 7 , he is guaranteed a "full right to the immovable property he builds and to the permanent improvements he brings about on the land by his labor or capital," and this right includes the right to alienate, to bequeath, and, where the right of use expires, to remove his property, transfer his title, or claim compensation for it [FDRE constitution, 1995, Article 40 (7)].

However, in many countries land ownership is not a constitutional issue, but in Ethiopia, because of its socio - economic importance, land ownership goes beyond being a mere policy matter (Woldegebreal, 2012, p.72). In doing so, the state ownership of land has been criticized by researchers and international donors who favor the neo- liberal economic thinking. The usual argument forwarded by these people against the state/public ownership of land is one that focuses on lack of tenure security. For them, State ownership of land by default creates tenure insecurity since, they argue, the government may use land as a political weapon by giving and taking it away as the case may be. They argue that the absence of tenure security for land users provides little or no incentive to improve land productivity through investment in long -term land improvement measures, increases transaction costs because of land disputes, and hinders the emergence of property market such as, credit availability/land mortgage (Ibid, 2012).

Paradoxically, the government rejects such fears as baseless; on the contrary, it claims that government provides better security as is now taken by regional governments. A good example is the land registration and certification processes which are being conducted in 'Agricultural Development Lead to Industrialization /ADLI/' regions (Amhara, Oromia, Tigray and South People), which enable farmers to have a land certificate for their holdings. This gives protection and security to the holder (Woldegebreal, 2013a, p.73). All the debates what I saw in the above is based on ideological discrepancies rather than practical studies. The other good research that inspired the researcher as well as a neutral perspective regards to land issues for the country like Ethiopia have been expressed in Dr. Daneal W/Gebreal Doctoral Thesis, 'Land Rights and Expropriation in Ethiopia', which states that: - "The private vs. state ownership of land by itself is not as such a decisive factor. What is important is whether or not there are adequate measures and regulations in place to guarantee tenure security, such as land certification, just compensation in the event of expropriation, long duration of rights, good governance, absence of corruption, and easy access of courts"(Ibid, 2013b). 
Ato Tamirat Demisse (2016), Animal Science Study Expert of ANRS/ BoLAU. I asked him what type of tenure arrangement do peasants prefer? He said that, to be assured the rights of peasants on rural land, the land is the common property of the state and the people. On the one hand, he justified, if the land is owned by the government only, it dictates the rights of peasants when the government needs for another purpose or fixed the values of the products. On the other side, if the land is privatized, peasants' sell their land at the time of hardship and the money will be serving for consumption. But after finishing it, a peasant migrates with his full family to another area. Then, he concluded that, if the government assures land certification, just compensation in the event of expropriation, and good governance to save the life of peasants, the land would remain the common property of the state and the people.

In the same voucher, the researcher is supporting the ownership of land by the state and people of Ethiopia and opposed privatization of the land holding system. Because neoliberals and their supporters argue for privatization of the land holding system for the sake of their ideological hegemony and indirect colonization (buying the land and wants to rule the peasants in their circumstance as well as loading their ideas even in the time of election). Whereas the ruling party inserted land issues in the constitution, not only for the sake of political dominance as neo-liberals think, rather for social equity and tenure security. Moreover, most of the new emerging states like Brazil, Russia, India, China and South Africa /BRICSs/ and Philippine, Indonesia, Nigeria and Ethiopia /PINEs/ were practicing state ownership of land. In doing so, these countries disprove the assumption of neoliberal economic thinking, state ownership of land leads to hinders of agricultural economy. Thus, if the government assures land certification, just compensation in the event of expropriation, and good governance under state ownership circumstance, the government should verify tenure security for land users; facilitate the emergence of property market such as, credit availability to save the life of peasants.

\section{The Scope of Land Rights and Laws in Amhara Region}

The federal government delegates, regional states with the power to enact rural land administration and land use law which is parallel to FDRE/ RLAUP. Similar to the federal land laws, the Amhara regional state land laws, Proclamation No. 133/2006 article, 6 (1) clearly stipulates that any person who demands rural land for free he/she must have been residing in the region and above the age of 18 years may engage in agricultural activity. According to the proclamation, Ato Fenta Dejen (2016), Head of Land Administration and Use Bureau stipulates that, age, residency and profession are the three important criteria to get rural land in the Amhara region. Again, Ato Fenta Dejen, referring to ANRS Proclamation No. 133/2006, gives additional expressions about 'use right' in that peasants have all the rights of an owner except sale and mortgage. In so doing, they can use the land for agricultural production and have full ownership to produce, to rent to fellow farmers, lease to investors, inherit and donate to family members. For this reason I asked him, do farmers have a sense of confidence to improve the land as their own land being the issue on sale and mortgage is not allowed? He said that, peasants have no hesitation being the land is others, rather they assume the land is their and have full confidence for any activity they improve on the land because the peasants have the right to use the land until their death and transfer through inheritance to their heirs.

As Ato Deribew Wubu (2016), a farmer in Raya-Kobo woreda (district), expresses about the use right as the following: - a peasant has a full right to produce what he wants on his holding land as well as advise to use any technology that is suitable for land fertility to produce more and more. Again he elaborates the use right being it is a state and peoples land, it is peasant's right to use, inherit, donate, transfer, and protect the land from any degradation or the farmer use it for agricultural activity either in subsistence farm or modern or commercialized system. But he states paradox to Ato Fenta, peasants have no a sense of confidence to improve the land as their own land, because the state takes away peasants land property for public interest without the permission of peasants.

In the same token, the researcher believes that, if the peasants have the right to seal and mortgage their own land beyond the right to use, it is difficult to save them from hunger, famine and migration. Because if this right is permitted, in times of drought they sell their land and migrate to cities. Thus, being they are farmers, they cannot work in factories as compared to urban dwellers and also the undeveloped industries and service of urban areas unable to accommodate these migrants. As a result, unemployment and social insecurity will be happening in the country at large. Furthermore, paradox to Ato Fenta, the researcher believes that, the use right is not absolute, even the ANRS proclamation No.133/2006 does not state any time limit for the use rights. Rather the state takes away private owned land property for public interest without the consent of the owner. So that the use right may expire where the land is needed for public purposes or failure of the holder to protect the land from degradation or where the holder desert the land and redistribution.

Regards to, 'the right to transfer holding right' through inheritance, donation and lease, Dr. Daneal W/Gabriel (2012), referring to Article 5 (2) and (Article 2 (5) of proclamation No 456/2005 states that, "a family member" as the following: - primarily a person to be a family member, he must permanently live with the farmer under the same roof; and secondly, he must totally rely on the peasant farmer for his life and has no other income of his own. $\mathrm{He}$ is under the control and administration of the farmer management element. This means, the law does not 
specifically require martial or blood relations for a person to be considered as a family member. Hence, a laborer who has no alternative income of his own and lives with the farmer without salary under the same roof may be considered as family member and eligible for inheritance. Paradoxically, it is not possible to inherit or donate rural land to one's children who live elsewhere or are engaged in other professions (Woldegebreal, 2012:49).

Ato Yehunew Abebe (2016), Deputy Head of Land Administration and Use Bureau, contends that peasants have the right to inherit their holding right as expressed in FDRE/ RLAUP. But it missed the situation of inheritance during interstate succession and the priority of heirs in case where the land holder died without a will. He emphasized that, to solve these controversial issues, the Amhara RLAUP clearly stipulates the priorities of inheritance of land among family members by will to engage in agriculture. Again referring to ANRS Regulation, No.51/2007 article 11(7), he clearly stipulates that, the manner of inheritance and the priority of heirs in case of intestate succession in that a farmer can inherit his land to fellow farmer or a family member by will and in the absence of a will, the land shall be inherited as follows: - minor children, if not children or other family members who have no land, if not children or other family members who have land, if not spouse who remains unmarried and continues living in the area of parents.

Similarly, Ato Ayizwachihu Chagne (2016), a farmer in Maksegnut woreda with regard to inheritance, he said that if any farmer wants to decide to inherit to his family by will, there is no restriction in the rules and regulations and in short it is possible to inherit. But if a farmer is dying accidentally without will automatically his sons and daughters will inherit the land if not his wife will inherit. What he exemplified the reality, his family was dying when he was at the age of 17, then he and his sister automatically inherited the land without third person intervention among other families provided they have no land (Interview with Ayizwachihu, 2016).

Respects to this, the researcher states that even if the Amhara regional land law seems a better provision in that it puts the mode of inheritance and the priority of heirs in case of intestate succession, it has a big problem in times of practice. Again the land laws are not curing the sons and doubters from mental and physical harassment when they inherit the land after their families died. Because after they took the land by operation of the law, their old family members are assassinating or disable them to hold the so called rural lands from the hands of the inherited one. In doing so, the researcher suggests that the Amhara Regional State will be establishing the legal ground to save the child's right. And the government should establish an orphan or trusteeship council for those childs to live temporally, until their growth up.

By the same token, if the deceased had no children to inherit the land, the law permits the spouse to inherit who remains unmarried and continues living in the area. Means, the spouse to inherit the land, will remain unmarried according to the law.If so, the rule against her human right because she has to remain unmarried. On the other hand, the spouse may make sexual intercourse with the one who lives in the same area who may or may not have spouses. In this way he or she may be discriminated by the society in every aspect of social issues. Thus, the researcher will recommend to the regional government to allow smoothly the word 'unmarried' in its land law or the government should modifiy its law for requiring of spousal consent for all transactions involving family or community land like Uganda.

With favors to peasants 'lease right', as I interviewed Ato Addisu Molla (2016), Land Administration Expert of Land Administration and Use Bureau, to what extent peasants have free discretion to decide on the amount of land and duration of time when leasing their land? Referring to Article 18 (6) of Proclamation No. 133/2006, he stipulates that, peasants have the right to lease out their holding for about 25 years without any restriction of the land amount of the external body.

Similarly, Ato Molla Kebede (2016), a farmer in Raya-Kobo woreda states that regarding to renting right, farmers can lease their farming land either to peasants or investors in between 25 years. He may also lease his farming land either three or ten years what he wants. In this regard what the researcher asked him, what amount of land peasants have the right to lease for peasants and investors? He was not able to fully answer the amount of land to be leased and he says, if peasants want to lease, they ask the land administration office what portion of land they will lease (Interview with Molla, 2016). From this point of view, the researcher notes that the land administration sector will raise peasants awareness about their right regards to land lease amount even if it is not clearly stated in the proclamation and land laws in general.

Daniel Weldegebreal (2013a) explained that, Oromia and Tigray Regional Land Laws clearly stated the size of lease land to protect peasants' displacement from their land. But in the Amhara Regional Land Law the size is not mentioned and peasants are allowed only to rent their holding. But if peasants rent more than their holding, and if the peasants had no another income for a livelihood, the remaining holding should not be enough to produce annual food consumption for his family or peasants rent the whole of his holding, the law does not protect peasants from eviction. In doing so, in order to protect peasants from eviction and migration, the Amhara regional state will be stipulated the size of land in which peasants' lease out (p.49).

Concerning the 'right to compensation during expropriation', Ato Fenta Dejen, advocates about the importance of the law in the Amhara region, to security of farmers right to their land as the following: - If framers lose their land only when the land is needed for public service, the government or other organ could not displace 
peasants from their holding without commensurate compensation. That is, the government bodies, private investors, or cooperative societies are obliged to pay compensation before evicting the holder, so it saves the evicted farmer from social and economic crises resulted from expropriation. Again he emphasizes the amount of compensation given to peasants in that a government has a duty to give the proportional amount of compensation to the looser for the development he made on the land. If land is available it will be given as a replacement. If there is none, then displacement compensation will be provided.

On the other hand, Ato Yigzaw Mengesha (2016), a farmer in Maksegnut woreda disagrees with the composition system among other rights of peasants. Primarily, in times of expropriation, the compensation value given to peasants is not enough and it doesn't consider the long lives of farmers. Surprisingly, he said that, the land is an eternal life of peasants and it is not sick and die as peasants sick and die. But the value of compensation given to peasants in the form of money is consumed in a short period of time before the peasants' sickness. Thus, to protect peasants from such situation, he prefers the compensation value should be land to land compensation (Interview with Yigzaw, 2016).

Similarly, Ato Amare Belay, a farmer in Raya-Kobo woreda (2016), said that, it is not a right of farmers rather it is a duty of farmers. Again and again he stressed that, 'expropriating peasants from their areas are similar to sending peasants to the war operation into battlefield'. Generally, farmers do not prefer compensation in terms of money. For example, what the researcher asked the ten interviewee peasants to make choice in the form of monetary compensation and a land to land compensation during expropriation, all of the farmers said that, we didn't hear such options, but if it is a right we need only land to land compensation which are not far from our locality (All the interviewee peasants, 2016).

By the same token, Dr. Daneal W/Gebreal (2013), stipulates on issues of compensation; a land to land compensation is the most preferable mode of compensation among Ethiopian farmers. The reason is that, for a farmer, land is not only a source of economy, but also a source of dignity and pride. To date, social status and prestige are determined based on the economic status of a person, and thereby on the size and fertility of land she/ he holds. Again he said that, land possession also enhances women's sense of freedom and self esteem. Then a landless person in rural areas is a wanderer without abode and social status. But most importantly, farming is the only skill and a way of life farmers can understand and be confident of than another assets (Woldegebreal, 2013b, p.258).

The researcher believe that compensation at the times of expropriation for public purpose /interest/ use is a common phenomenon, not only in Ethiopia but also throughout the world and it is the power of the government like other policy issues. But when we come to Ethiopia unlike other states, the compensation system is compensation for property on the land, compensation for improvement to the land, replacement land without the absence of replacement land is displacement compensation. Then a person who lost a land automatically is permitted to displacement compensation in the form of monetary compensation for his /her loss in addition to the compensation provided for the property situated on the land and the improvements she/he brought about on the land.

In doing so, the so called monetary compensation assumption is equivalent to ten years' compensation. That is the displacement compensation is calculated by taking the average income of the past five years and multiplying it by ten. Because of this calculation peasants are not benefited. Besides these farmers who want to leave their locality in search of food and other works to another potential area join the social queues considered another burden to the government. So, the researcher recommended that, if the land is needed for temporary purposes, the displacement compensation may be needed unless it is permanent, the government will reward peasant's compensation for improvement to the land and land as replacement land. Or the government proposes a mechanism like Kenya, for redistribution of land and resettlement of internally displaced people and protecting their land rights from unjust and illegal expropriation and also like Tanzania prompt, fair and adequate compensation. If not the rights of farmers will be denied and the slogan that says "land is the common property of the state and the people"- will remain as a paper value.

Ato Fenta Dejen (2016), referring to the federal rural land law FDRE (2005), Proclamation No. 456/2005 article 6 (1) stipulates that any holder of rural land shall be given 'holding certificate' to be prepared by the competent authority which indicates the size of the land, land use type and cover, level of fertility and boarders, as well as the obligation and the right of the holder. Whereas ANRS Proclamation No.133/2006,article 24 (1) states that, any person, granted rural land shall be given the land holding certificates in which the details of the land are registered by the Authority prepared by his name and his photograph fixed thereon. The holding certification is a legal certificate of the holder.

Ato Marie Gzahegn, a farmer in Maksegnut woreda, concerning the rights of land registration and certification expressed that land registration and certification is the highest level of peasants ownership rights on their land as well as tenure security. Additionally, he stressed about its benefit for farmers as a protecting mechanism from land gravers and disputes between and among farmers from expanding the communal land as well as government land, from taking the idle land as their own possession and encroachment of one farming land 
from others (Interview with Marie, 2016).

On the other side, Ato Kassa Aweke, a farmer in Raya-Kobo woreda states that, since land registration and certification existed in the rural areas, every peasant has been protecting their land in advance from land degradation, overgrazing, deforestation as the same as protecting their body from enemies (Interview with Kassa, 2016). Similarly' I asked Ato Beyene Wesen, a farmer in Maksegnut woreda (2016), do you believe that your holding rights are secured as result of having a certificate of holding. He said that yes, I believe and that is why I am improving my farming land to produce more and more from one season to another season like I washing my body week to week to be active and healthy.

Ato Tamirat Demisse (2016), Land Administration Expert of Land Administration and Use Bureau, concludes that land registration and certification in an underdeveloped society in general and particularly in Ethiopia is the cornerstone of peasants. Because without it peasant's livelihood will be scattered as pastoralists and thinking development, growth, prosperity and civilization is immoral. Again he stressed that, if land registration and certification exist, it will protect land holding and land use rights of landholders will confirm that land holding and land use rights are legally secured. The aforementioned is what most scholars said, the ultimate goal of certification is to achieve environmental sustainability, economic growth, poverty eradication and establishing good governance.

The researcher believes that to secure land tenure in addition to land certification, adequate measures and regulation is the driving force of peasants to guarantee tenure security, such as long duration of rights, absence of corruption, and easy access to courts. Because most of the cases in the court are rural land-related issues and even a case will remain a year in the court with the absence of easy access to the court. Even if these ideas already exist in the policy framework of the Federal and Amhara region, the government must be strengthened to guarantee tenure security.

Furthermore, the researcher suggests to regional BoLAU to train and build the capacity of peasants about their rights and duties with regards to who is the owner of farming land and the product over it. Because among the ten interviewee peasants answered the question whether they know their rights with respect to the land they hold, four of them are not aware either if the land is their own private property or public. Plus, they have not full of knowledge about the use of land certification as well as not having enough knowledge as to what extent landholders have the right on the farming land.

In the same token, Molen (2008) stressed that, the policy documents of a state must enhance institutional and human resource capacity through education and training of land administration and management professionals as well as peasants at a variety of levels. Again he illustrates that, Kenya, Tanzania and Malawi have been created, a human resource capacity to operate the computerized infrastructure for land delivery. Specifically, Kenya proposes the education and training center to ensure that land use plans and farmers' capacity building are applied as tools for effective land use management (p. 42).

\section{Limitations of Peasants Right over Rural Land}

Ato Addisu Molla (2016), Land Administration Expert of Land Administration and Use Bureau, concerning the requirements of obtaining farming land states that, a farmer who live around in his birthplace and he is a farmer will get farming land if there is an idle government land which is not occupied by other farmers. But if there is no an idle and government land, a person will be engaged in his family farming land either based on their agreement, i.e. one forth, one third, etc. or if he is married, his family may give some part of the farming land for his livelihood. If all these are not available, he needs other options in which he will serve with another farmer who has large farming land as a laborer or in temporal contract.

In another way, the researcher asked him, why a farmer got farming land from another area away from his residency if there is free land? He said that it was good, but the government did not provide a right to give land from another area because of the same problem in that area and even if there is free land, it will be given to those youths who have no land in the area. Again the researcher asked him can you say this policy is good? He said yes. It is good, because it hinders farmers migration out of their area and also farming land is the same problem of every part of our region. So every farmer who has no land can work on a contract either on his family or other person who are old enough to farm his land.

On the other hand, the researcher asked Ato Solomon Berihun, a farmer in Raya-Kobo woreda, do profession and residency discourage farmers from moving to cities in search of alternative lives and people from moving and working in other areas away from their residency? He said that, the requirements of obtaining farming land, such as profession and residency are not good, because whether you believe or not, most of the farmer's sons after graduated their first degree, they have no government jobs as well as farming land. So that the government must be modify its land policy and recruit or give farming land from settlement areas like Metema and Jawi (a large farming land arranged for investors by the government) to those who have no land or government jobs. Unless, it is difficult to live without land from other regions, out of their area (Interview with Solomon, 2016).

All the interviewee peasants except Ato Solomon Berihun, advocate the land policy in which profession and 
residency are the basic qualifications of farmers to get into farming land. They stressed that, unless this qualification is taken into consideration, the land will be given to persons who are not peasants but in the form of peasants in another area. Then the real peasants will become landless whether in their area or away of the area because a person who is educated has a chance to get land everywhere but an illiterate peasant remains landless even a barren land. Finally, they concluded that, land became a source of war between and among peasants who have no land on the one side and the so called peasants' i.e. unreal peasants who have land on the name of peasants on the other hand.

Having these all in mind, the researcher believes that all the three requirements; residency, profession and age are important criteria for developing countries like Ethiopia. Because, on the one side there is a shortage of land everywhere in the country and on the other hand the population pressure increase from time to time. So that in this circumstance giving land out of these considerations, leads to injustice and unfair distribution of land to peasants and do not control the frauds and embezzlements against an innocent peasant where the land is given everywhere to everybody. Again, if the government grants farming land to every professional, it denies the creation of science and technology because of the fact a person does not work in that specialized profession and instead moves into farming out of their profession.

Regarding the impossibility of inheritance related to blood and marriage, Ato Muhabaw Teshome, a farmer in Maksegnut woreda (2016), notifies that, such restrictions alter the child- parent relationship and it hinders family integration in different aspects of social ceremony and grief. As the law excludes them from inheriting their parent's rural land and allowing it to any person who permanently lives with their parents, leads to family instability between and among societies. In addition, the children who live in another area become unwilling to support aging parents. Aged peasants are also morally and mentally discriminated against because a neighboring peasant will inherit their land. Finally, when they die, their family members who have not inherited that land remained in their funeral celebration as well as the remaining child relations will not be peaceful.

Pertaining to this restriction of inherited land to the family member who engaged in other professions and lives in another area, all the interviewee peasants disagree with the land policy in which it creates a conflict between family members as well as honesty among the families. Thus, the government will arrange its rural land inheritance policy. Means, rural land inheritance should be with family members instead of any person who permanently lives withholder of holding right. Paradoxically, Ato Fenta Dejen, Heads of Land Administration and Use Bureau, states that a laborer who has no alternative income of his own and lives with the farmer, without salary, under the same roof may be considered as family member and eligible for inheritance. Again he said that beyond this the Amhara/ RLAUP even goes one step ahead by allowing inheritance of land by will to any farmer engaged in agriculture (Interview with Fenta, 2016). The researcher supports the fact that the law prohibits the farmer to inherit or donate rural land to one's children who live elsewhere or engaged in other professions. Because the rationale behind such rule seems that since the land belongs to the state and the people and not a private one, it has to be shifted to those who are in need of it, irrespective of their blood relations.

Concerning on the duties of peasants, Ato Yehunew Abebe, Deputy Heads of Land Administration and Use Bureau (2016), said that farmers have a full holding right and can bequeath it to his family member; including the right to acquire property thereon except selling and mortgage of the land. The supporting reason to the aforementioned he argued that, if land is sellable then over time it may fall in the hands of speculators and brokers. Also, peasants may remain jobless after selling their land and will migrate to cities. Consequently, because of shortage of industries in urban areas, unlike developed states, the poor state is unable to feed the migrant peasants in urban areas and that is why our government strongly undermines privatization of land in Ethiopia. Beside of this, the researcher asked him; if farmers want to sell their land during the period of hardship; can that sell? He said that even in the time of drought and famine, peasants prefer renting their land and move to other areas in search of food rather than selling the land.

Again Ato Tamirat Demisse, Animal Science Study Expert of Land Administration and Use Bureau (2016) argue that, land sale and exchange is not preferable in Ethiopia. Because land is a common property of the State and the people, it is not for sale under privatization that is why we said always it is the best mechanism to protect the peasants against market forces. Furthermore, he argued that private ownership of rural land would lead to massive eviction or migration of the farming population, as poor farmers would be forced to sell their plot of land to investors and urban speculators in times of hardship. Surprisingly, all the interviewee peasants advocate the land policy in regards to prohibition of selling the land. Again and again they stressed that, selling the farming land is as giving the child's of peasants to inhumane persons or simply cannibals.

The researcher argues that, public ownership of land is the best mechanism for the developing country and to transform into a developed state. Because every developed country around the world today did not allow privatization of land in their infant stage, rather they were followed state ownership of land until they became industrialized. In the same token, in Ethiopia land is under ownership of the state; means peasants are not the owner of rural land rather they have using rights. In doing so, prohibition of sale of rural land in Ethiopia is the cornerstone of peasant's livelihood unlike liberals. 
Again, the researcher believes that if the peasants sell their land to investors and work as a laborer in their original land, morally they will be depressed and become hopeless. Secondly, in times of election, they cannot elect who they want because of the high influence of the owner unless otherwise the holder may evict them from their project. Thirdly, if it happens, peasants will migrate to another alternative area in search of work especially to urban areas. In urban areas like Ethiopia because of underdeveloped industries and service, the unemployment rate will increase and they became hopeless. Finally, they will force to steal another person who has money and capital and because of these frustrations and aggression will emerge in urban areas and then it leads to revolution and state of collapse. Therefore, selling the land in agrarian state is an obstacle of the development and hindrance of growth.

Regarding the issue of, prohibition to use rural land as collateral, Ato Fenta Dejen, Head of Land Administration and Use Bureau asserts that, an investor may lease land from individual farmers, and from the Government. In practice, the land which is rented from the government that is given as collateral to banks whereas the land rented from peasant farmers is not given as collateral to banks. The justification is that the land rented from peasants is too small to pass it as mortgage and the peasant may not agree that his land be given as collateral to banks (Interview with Fenta, 2016). On the other hand, Ato Addisu Molla, Land Administration Expert of Land Administration and Use Bureau stipulates that, the law denied peasants to use holding right as collateral to have access to credit, while allowing investors to use their lease right for the same purpose. In doing so, he contends that as peasants and farmers- have a potential to pay back, the law will balance the rights of peasants and investors (Interview with Addisu, 2016). In line with this, all interviewed peasants told that, this prohibits peasants from access to credit for further investment in their land. These are problems which are attached to the granted rights of peasants. Peasants do not have free discretion to decide on the amount of land and duration of time when leasing their land. So the ANRS land law will arrange its proclamation regards to collateral and treat farmers at the same as investors (All interviewed peasants).

As for expropriation, Dr Daniel W/Gabriel lay down his assumption as the constitution does not recognize land as a private property being it is in the hands of the state and peoples. What is considered as private property in the constitution is any other property planted or erected on the land by the skill, labor or capital of the person. Therefore, the objects of compensation under the present legal regime are building plants and other similar things, save the ground or land it. This means the compensation valuation does not consider, among others, the value of location, and this significantly reduces the amount of compensation payable to the owner. Again he said the principle followed in today's Ethiopia is the "taker's gain" principle which stresses that the compensation paid must consider the original or undeveloped purpose of use of the land rather than its futuristic potential (Woldegebreal, 2013b, p.230).

In line with this, Ato Tamirat Demisse, Animal Science Study Expert of Land Administration and Use Bureau disagree with the compensation at times of expropriation, valuation is only for private property acquired over the land, not account loss of use right. Such issues were left for the federal land expropriation proclamation, which defines the public purpose broadly in the manner that jeopardizes the peasants' rights over their land. Moreover, the proclamation exclusively entitled administrative body to decide on the existence of public interest on certain land and the holder cannot complain against the legality of the decision by appealing to the court since the matter is made unjustifiable matter. Furthermore, the proclamation depicts assessments of compensation to be held by political organ without enabling the holder to participate (Interview with Tamirat, 2016).

All the interviewee peasants strongly disagree with the compensation paid in times of expropriation for public interest, in which the compensation value do not much that of the value of their property. Then if the government establishes a land to land compensation, it will be the most preferable mode of compensation for farmers because land is the only endowed source of economy and livelihood of peasants. Unless otherwise the law provides land to land compensation modality, the amount of compensation awarded is injustice and unfair as well as denied the right of peasants. Finally, they hopefully said that, we expect our government will modify it.

In the same token, Ato Fenta Dejen, Heads of Land Administration and Use Bureau, denies compensation paid in peri- urban land in the Amhara Region. That is the land found in between rural administration and an urban one. Means, the land is found in the peripheries of towns and cities. In doing so, at the times of expropriation, peasants don't benefit from value of compensation. As a result, to commensurate the value of compensation and land displacement, the regional government shifted such lands as part of the rural administration. In times of urban expansion, it will be acquired by urban administration through the expropriation process in which the compensation value will increase in rural land than compensation in urban land. For this reason, Ato Fenta acknowledged that, the ANRS council established a regional administration council guideline /RACG/, as rehabilitation and tenure administration to expropriated landholders for the public use (Interview with Fenta, 2016).

Again, he emphasized by referring to Guideline No.26/2008, art. 13, any peasant who lives in the peripheries of towns and cities whose land is either wholly or partially expropriated, will get land for housing in urban areas in addition to compensation for expropriation and the property on the land. This means that the expropriated one will get land, urban agricultural land or land for shop center as well as land for industry shed and agro processing 
land if they came in the form of association. On the other hand, if a farmer has a son whose age is beyond 18 , he will get a house land in urban areas the same as the land given to his father (Ibid).

The researcher stipulates on the problem related to expropriation in the region is not only because the compensation value is less than that of the losing one, but also unequivocal compensation regards to morality, distance and material values of the expropriated one. So that, among others land -to - land compensation is better for those especially who live in areas adjacent to urban areas. The same with Ato Fenta's argument the researcher advocates the regional government in which it promulgated the above guideline as a better mechanism to absorb the farmers into the urban life by providing them residential plots on the site or somewhere within the urban expansion zone.

\section{Conclusion and Recommendation Conclusion}

Currently, in Ethiopia all rural lands and natural resources are vested in the hands of the state and the people. Because of this constitutional provision, peasants shall not have ownership rights to the land itself, rather they are guaranteed the full right to the immovable property they build and to the permanent improvements they bring about on the land by their labor or capital. Even if there are different arguments regarding to public ownership of land, peasants would prefer land is the common property of the state and the people to be assured the rights of peasants on rural land. Under the rural land laws, peasants have different rights. Primarily, the rights given to peasants are free access to rural land with lifetime rights -holding right to the land in which they can get rural land without paying if and only they fulfill the requirements of residency, profession and age. Secondly, they have the right to transfer holding right through inheritance, donation and lease/rent to relatives.

But their usage is restricted for different reasons and peasants are not interested in this right as a right because, among others with the impossibility of inheritance related to blood and marriage. Even if the peasants have the right over rural land, there are also limitations over holding right. That is restrictions in regard to the right to sell, mortgage and change rural land as well as the government may expropriate private property for public purposes, subject to payment in advance of compensation commensurate to the value of the property. The other limitation is, in the time of expropriation there is no adequate compensation for loss and not considering the distance of the location, moral right and material values of the expropriated one. In doing so, the peasants are strongly blaming the compensation value which is done less than that of the value of property. Moreover, limitations regard to prioritization of heirs in case of intestate succession (when the deceased died without a will) and limitations on the rights of inheritance, donation and collateral. Because of these problems, the peasants are blaming the land policy and requesting the government to modify those issues.

\section{Recommendations}

Accordingly, all the above arguments and conclusions, the researcher recommended the following solutions to the existing government to develop or strengthen the tenure security through state ownership of land rather than privatization of land. First, the regional government shall modify and improve the existing compensation in the event of expropriation, and it must incorporate every material value, including distance as well as moral values at the time of expropriation or established land to land compensation like Tanzania. Second, the Amhara regional state should establish the legal ground to save the children from mental and physical harassment when they inherit the land after their families died because they are exposed to harassment from the family members who have not landed. Thus, the government should arrange an orphan or trusteeship institution until they grow up.

Third, the Amhara regional land law stipulates priority of heirs in case of intestate succession and give right to peasants regards to the free discretion to decide on the amount of land and duration of time when leasing their land. It also will be arrange its proclamation regarding to collateral right of farmers as the same as investors. Fourth, regards to the spousal right to inherit the land if she/he remains unmarried and continues living in the area, the regional government should pass smoothly the word "unmarried" in its land law or the government should modify its law like Uganda, without any restriction requiring spousal consent for all transactions.

Fifth, the government should revise the rural land proclamations and liberate some of the restrictions imposed on rights such as rent, donation and inheritance. The government must strengthen its policy framework, to guarantee land tenure, land certification, is the driving force of peasants to guarantee tenure security, such as long duration of rights, absence of corruption, and easy access to courts. Because most of the cases in the court are rural land-related issues and even a case will remain a year in the court with the absence of easy access to the court.

Six, ANRS BoLAU should train peasants to create awareness about their rights and duties with regards to who is the owner of farming land and the product because all farmers in the region do not have the same conception. Lastly, the institution of Land Administration and Use Bureau must be integrated with the other governmental sectoral institution (Water, Road, Agriculture, etc.), Agricultural Research Institutions and Land Law Department of Bahir Dar University. And the respective leaders of Land administration (especially Woreda and local leaders) will take the awareness creation or training with Land Law policy and general policy activities. 


\section{REFERENCES}

\section{List of Books}

Adal, Y. (2009). Rural land tenure and women's right in Ethiopia', in Muradu Abdo (ed.), land law and policy in Ethiopia since 1991: Continuities and changes. Ethiopian Business Law Series 3(67).

Alemu,A. (2009). Compatibility between rural land tenure and administrative policies and implementing laws in ethiopia. Ethiopian Business Law Series 3(68).

Bekure, S. (2006). Standardization of rural land and cadastral surveying methodologies. The Ethiopian experiences. ELTAB:Addis Ababa.

Belay, A. (2010). The effects of rural land certification in securing land rights: A Case of Amhara Region. Netherland International Institute for Geo-Information Science and Earth Observation, ENSCHEDE.

FAO. (2002). Land tenure and rural development. Rome Land Tenure Studies 3.

Feyissa, R. (2006). Farmers' rights in Ethiopia: A Case Study. Norway Fridtjof Nansen Institute.

Gerstter, C. (2011). An assessment of the effects on land ownership and land grab on development. Brussels Policy Department DG External Policies.

Hejase, A.J, and Hejase, H.J. (2013). Research methods: A practical approach for business students, 2nd Edition, Masadir Inc: Philadelphia.

Molen, P.V.D. (2008). A comparative study to land policy in 9 countries in Africa and Asia. GIG Working Week, Sweden: Stockholm.

Rahimato, D. (2004). Searching for tenure security:The land system and new policy initiative in Ethiopia. FSS Discussion Paper, Forum for Social Studies: Addis Ababa.

Seifu, G. (2009). Rural land tenure security in the Oromia national regional state'. Ethiopian Business Law Series 3 .

Snare, F. (1972). The concept of property. American Philosophical Quarterly, 9.

Teklu, T. (2014). Rural land rights and security in cultivated highland Ethiopia: Incremental reform but persistent uncertainty. International Journal of African Development.

UNECA, (2004). Land tenure systems and their impacts on food security and sustainable development in Africa. United Nations Economic Commission for Africa.

Weldegebriel, D. (2012). Land rights in Ethiopia: Ownership, equity, and liberty in land use rights. FIG Working Week Rome.

Woldegebreal, D. (2013a). Ethiopian Land Law textbook. BahirDar University Institution of Land Administration, BahirDar.

Woldegebreal,D. (2013b). Land rights and expropriation in Ethiopia, (a Doctoral Thesis, Sweden Royal Institute of Technology (KTH)).

World Bank. (2003). Policy Research Report: Land Policies for Growth and Poverty Reduction. Washington, D.C.: World Bank.

Zewdu,M. (2002). Sustainable development in Ethiopia. Report of Assessment of Activities and Issues Relevant to the Review Process of the Earth Summit 2002 in Ethiopia.

\section{List of Laws and Proclamations}

ANRS Rural Land Administration and Use Proclamation. Proclamation No. 133/2006, Article 6 (1), 18 (6) and 24 (1).

ANRS Rural Land Administration and Use System Implementation. Council of Regional Government Regulation No.51/2007, Article 11(7).

ANRS Rehabilitation and tenure administration to expropriated landholders for the public use guideline. Guideline No.26/2008, Art. 13.

FDRE (1995). The Constitution of the Federal Democratic Republic of Ethiopia. Article 40 (4), (5), (7) and 52 (2).

FDRE Rural Land Administration and Land Use Proclamation. Proclamation 456/2005, Article 5 (2), 2 (5), 5 (1) and $6(1)$.

Ministry of Lands, Housing and Urban Development (2007). Drafting the National Land Policy - Working Draft 3, Kampala, Uganda.

\section{Interviews}

Interview with Ato Addisu Molla, Land Administration Expert of Land Administration and Use Bureau, Bahir Dar, April 28, 2016.

Interview with Ato Amare Belay, a farmer in Raya-Kobo woreda, 01 Kebele, April 8, 2016.

Interview with Ato Ayizwachihu Chagne, a farmer in Maksegnut weoeda, Chasera mantero Kebele,March 23, 2016.

Interview with Ato Beyene Wesen, a farmer in Maksegnut woreda, Jaira Kebele, March 23, 2016.

Interview with Ato Deribew Wubu, a farmer in Raya-Kobo woreda, 01 Kebele, April 8, 2016. 
Interview with Ato Fenta Dejen, Heads of Land Administration and Use Bureau, Bahir Dar, April 28, 2016. Interview with Ato Kassa Aweke, a farmer in Raya-Kobo woreda, 01 Kebele, April 8, 2016.

Interview with Ato Marie Gzahegn, a farmer in Maksegnut woreda, Lemba-Arbaetu kebele,March 23, 2016. Interview with Ato Molla Kebede, a farmer in Raya-Kobo woreda, 01 Kebele, April 8, 2016.

Interview with Ato Muhabaw Teshome, a farmer in Maksegnut woreda, Jaira Kebele, March 23, 2016.

Interview with Ato Solomon Berihun, a farmer in Raya-Kobo woreda, 01 Kebele, April 8, 2016.

Interview with Ato Tamirat Demisse, Animal Science Study Expert of Land Administration and Use Bureau, Bahir Dar, April 28, 2016.

Interview with Ato Yehunew Abebe, Deputy Heads of Land Administration and Use Bureau, Bahir Dar, April 28, 2016.

Interview with Ato Yigzaw Mengesha, a farmer in Maksegnut woreda, Dasdinizaz Kebele, March 23, 2016. 